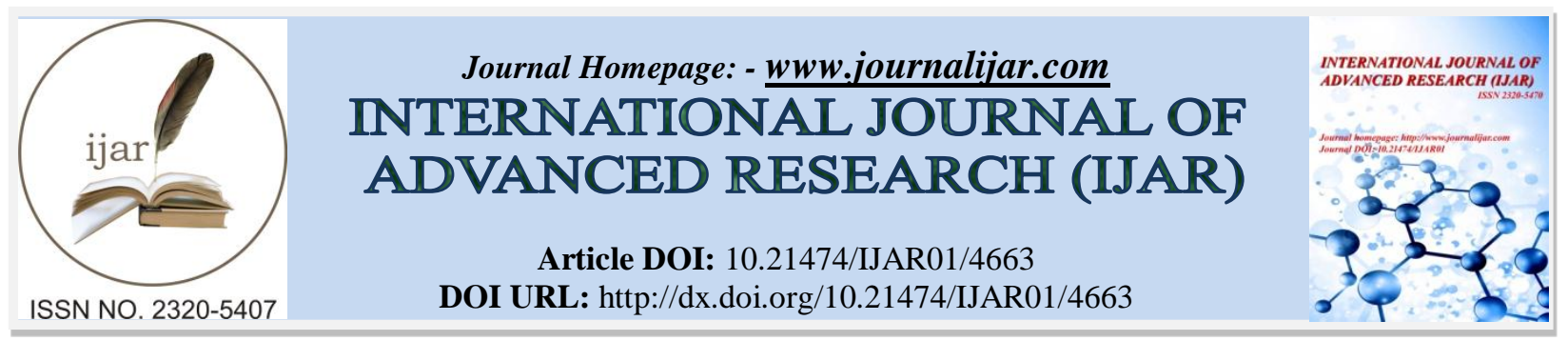

RESEARCH ARTICLE

\title{
KNOWLEDGE MANAGEMENT PROCESS: THE CASE OF TEQUILA INDUSTRY IN MEXICO
}

\author{
Marco Alberto Nunez Ramírez, Rosalva Irma Castro Alvarez, Altayra Geraldine Ozuna Beltran, Ricardo \\ Martin Arreola Gonzalez, and Valeria Carolina Leon Ramirez. \\ Instituto Tecnológico de Sonora. Sonora, México.
}

\section{Manuscript Info}

Manuscript History

Received: 28 April 2017

Final Accepted: 30 May 2017

Published: June 2017

Key words:-

Process, knowledge management, tequila industry.

\section{Abstract}

The aim of this research is to identify the knowledge management process in the tequila industry. The steps of the SECI model were taken as a starting point: socialization, externalization, combination and internalization. Through a mixed methodology, it was used a test for staff and executives of tequila companies, as well as semistructured interviews with researchers and academic experts in the study area. It was found that the process is performed by a fragmented way, where significant items as information, innovation, management manuals and databases are required; being the figure of the "master tequilier" which requires more attention. The union of enterprises with public institutions, and universities can be a strategic element that, through knowledge, can develop the tequila in the alcoholic beverage market.

Copy Right, IJAR, 2017,. All rights reserved.

\section{Introduction:-}

Knowledge has gained great relevance for the economy and organizations (Roos et al, 2001); which has been postulated since Matchup (1962) and Drucker (1969). Subsequently, this was retaken within Resources Based View (RBV), where such intangible asset is considered as a resource that can give a sustained competitive advantage (Barney, 1991); as well as Knowledge-Based View (KBV), which considers it as an element that adds value through information, technology, and skills (Grant, 1996).

Knowledge is an asset and, like all assets, has to be managed, because whoever finds and controls it wins (Stewart, 1998). Nonetheless, Brooking (1997) argues that studies in this area have shown that in practice only about $20 \%$ of the knowledge available to the company is used. Therefore, knowledge management (KM) has emerged in order to plan, coordinate and control knowledge flows that are produced in the company (Bueno, 1999).

However, despite all the theoretical and empirical considerations that support the relevance of knowledge management for development and competitiveness, in Mexico the implementation of strategies that generate and transmit knowledge have had a low development (Casalet, 2010; Sánchez and Ríos, 2011). This is because there is a low understanding of what knowledge is and how companies can exploit it.

An example of this is the tequila industry, which, although it began to professionalize in the 1990s (Macías and Valenzuela, 2009), it has not taken advantage of the knowledge derived from its value chain (Bowen, 2012). This is partly due to the fact that knowledge management is not considered as a strategic resource (Boonman, 2009), causing problems related to innovation, use of technology and competitiveness by tequila SMEs (Nassau, 2000). 
Likewise, it lacks research, which is something exclusive of public institutions, where few companies participate (Luna, 2009).

This industry is characterized as an oligopoly (Coelho, 2007; Macías, 1997), because of according to Martínez (2008) only three companies (Cuervo, Sauza, and Herradura) control 60\% of the market. It is important to note that part of its success was caused by its commitment to use knowledge as a way to maintain and increase productivity and competitiveness, through research and development activities, as well as the use of external sources of knowledge, mixing traditional and modern (Casas, 2006). Therefore, there is a need to create an environment that favors the dissemination of knowledge among companies and other organizations such as universities and research centers (Coelho, 2007).

Thus, it is required that tequila companies -especially MSMEs- employ KM as a strategic element to compete. Even the agave crop has not been thoroughly studied and the available information is incomplete, this has generated the need to generate greater national knowledge in the area (Rulfo et al, 2007). Certainly in recent years the tequila industry has opened up to the knowledge economy (Casas, 2006); however, much remains to be done.

If research in strategic management is clear that knowledge is a basic resource to be competitive (Barney, 1991; Grant, 1996; Nonaka, 1994); and at the same time, evidence has shown that industry leaders employ knowledge as the basis for their success (Casas, 2006). Then the following research question is proposed: How is knowledge management characterized within the tequila industry?

\section{Knowledge Management Process:-}

It starts from the premise that within organizations two types of knowledge are required: tacit and explicit (Nonaka, 1994). The first is transmitted orally, as it is not found in manuals, books, databases or archives, because it is created and disseminated informally (Stewart, 1998). While the explicit can be written and relatively transferred from one person to another in an orderly manner (Nonaka and Takeuchi, 1995). Both types constitute an infinite cycle that consists in identifying the tacit knowledge to make it explicit (Stewart, 1998).

Although there is not a universally accepted definition of KM by the specialized community, a certain consensus has been found that considers it as a process (Madrigal and Núñez, 2013), which is observed in Nonaka and Takeuchi (1995) as well as Wiig (1997). It is noteworthy that this process reflects how individuals learn within the organizational context (Edwards et al, 2005). Its creation is done through the interaction of tacit and explicit knowledge, which allows to postulate four modes of knowledge conversion (Nonaka, 1994): socialization (harmonized knowledge), externalization (conceptual knowledge), combination (systemic knowledge), and internationalization (Nonaka and Takeuchi, 1995).

\section{Socialization:-}

It is a limited form of knowledge creation, because it can not be used by the organization. It implies the conversion of tacit knowledge through interaction between people, without the use of language, observation, imitation and practice (Nonaka and Takeuchi, 1995).

\section{Externalization:-}

(From tacit to explicit). It is a process that articulates the tacit knowledge within explicit concepts, creating a synchronized and understanding through the autonomy of the employees (Nonaka and Takeuchi, 1995). In addition, it stimulates reflection through dialogue, becoming essential the formation of individual knowledge and group cohesion (Nonaka, 1991).

\section{Combination:-}

It is based on the conversion of explicit knowledge into more complex elements, where its diffusion, edition and systematization are the main part (Nonaka, 1994). It includes individual exchange and mixing of different knowledge through means of communication, interviews, telephone conversations and computer networks, which can generate new knowledge (Nonaka and Takeuchi, 1995). 


\section{Internalization:-}

It aims to create work environments allow the appropriation of knowledge by the members of the organization. Here it is required that knowledge be verbalized and stored in documents, manuals and databases that allow the transfer of explicit knowledge to the tacit (Nonaka and Takeuchi, 1995).

\section{Tequila Industry:-}

Tequila is an alcoholic beverage obtained by distillation of agave tequilana weber (Valenzuela-Zapata, 2007). Its industrialization extends from the field -where the agave is harvested-to its manufacture and commercialization (Díaz, 2007). Its elaboration is the result of a mestizo heritage, which combines pre-Hispanic methods for the extraction and processing of mexcalli, and European processes of fermentation and distillation used in the preparation of beverages (Walton, 1977). In Mexico was declared the area of denomination of origin Tequila by decree of the Mexican Federal Official Gazette on October 14, 1974 (Rulfo et al, 2007). This delimits the geographical specifications to cultivate agave tequilana weber within Mexican territory (Macías and Valenzuela, 2009). In recent years tequila industry has become one of the most important products of the Mexican transnational trade (Coelho, 2007).

The tequila industry organization has certain characteristics: on one hand, it is oriented toward a dependence on foreign capital and multinational companies (Coelho, 2007), which disadvantages MSMEs; and on the other, according to COFUPRO (2003) there are problems that affect its competitiveness, such as disorganization, low technology transfer and poor technical assistance. Therefore, there is a need to create an environment that favors the diffusion of knowledge between companies and research centers (Rulfo et al, 2007).

\section{Methodology:-}

The present research is of mixed type, exploratory and casuistic, with a non-experimental design. It is only through a mixed methodology that it is possible to explain a complex industry such as the tequila industry, which entails a great mosaic of cultural, historical, social and geographical elements.

\section{Study Sample:-}

Within the quantitative part, a convenience sample was obtained, consisting of 39 tequila companies from Jalisco, Mexico, where $25.6 \%$ was integrated by micro-enterprises, $38.5 \%$ small, $23.1 \%$ medium and $12.8 \%$ large companies, which were oriented towards both national and international markets (59\%), as well as international markets $(15.4 \%)$. While for the qualitative part, nine semi-structured interviews were conducted to academics who are knowledgeable about the tequila industry in different areas such as history, intellectual property, business, research, regional studies, agronomy and chemistry.

\section{Measurement instrument:-}

A KM questionnaire proposed by Mihi et al (2011) was used, which is based on the Nonaka and Takeuchi's (1995) SECI model. This was formed by 11 items distributed in the four parts of KM process: socialization (3), externalization, (3), combination (3) and internalization (2). Items were answered using a Likert-type scale with five options to respond, ranging from 1 (Strongly disagree) to 5 (Strongly agree).

On the other hand, interviews were semi-structured, however, these were grouped into two basic questions: What way do you consider that knowledge is generated, transmitted and applied throughout the tequila production chain? What is the relevance of the use of ICTs, technology and innovation in the tequila industry? The first question was oriented to obtain global information on KM; while the second tried to know how tacit knowledge becomes explicit.

For the information processing, SPSS was used in the quantitative part and ATLAS.ti for the qualitative. A hermeneutic process of data was used, which pretends to interpret a meaning within a context (Ferrater, 1964), seeking to understand the phenomenon in its multiplicity of elements (Nataliya and Inciarte, 2012), in this case by a mixed way. KM constructs of SECI model were used as categories: socialization, externalization, combination and internalization.

\section{Results and Discussion:-}

It was found that tequila companies are giving greater importance to the KM. "People, who have knowledge if they do not transmit it, it is lost" (Interview 4). "Some companies are transmitting knowledge" (Interview 3), which has 
been caused by the increase in the integration of tequila industry. The results are presented according to the four stages of SECI process, combining quantitative and qualitative data (See Table 1 and Figures 1 to 4 ).

\section{Socialization:-}

From quantitative data, here the highest values were found $(M=3.87 ; S D=.787)$-this shows that there is some openness to the transfer of knowledge-; while in qualitative results, opposite versions were found. On the one hand, it is believed that the regionalization of industry allows innovation. "As there is no technology outside of Mexico for the industry, they have to open themselves to innovation" (Interview 2). For others, innovation is only used by leading organizations. "It has improved in large companies. The strongest companies have bet heavily on the technological reconversion in the industrial area as in the part of primary production" (Interview 8). Also, "small and medium-sized businesses are not on a par with technology with the big ones and are the least resourceful" (Interview 3). "The companies that are focused on innovation, have bet by technology, innovating in administrative and technology ways. They bet to be leaders and winners" (Interview 9). While for other tequila companies "innovation is not enough, there is innovation in the field and the commercialization" (Interview 4).

\section{Externalization:-}

According Nonaka (1991), at this stage, the information becomes a fundamental element for the formation of individual knowledge and the cohesion of the group; despite their importance, at this stage the lowest means were found: The dissemination of knowledge is encouraged $(M=3.14 ; S D=1.10)$ and Progress reports are distributed $(M=3.16 ; S D=1.20)$ (See table 1). For some the tequila "is a sector that has opened up importantly ... It has opened drastically to the use of technology, use of information... If before it was very rare to document the processes now and practically all the documents" (Interview 2). However, for others, in the industry, there are not enough reports and progress: "I guess some companies have their manuals" (Interview 4).

\section{Combination:-}

The information is in possession of leading companies and the master tequila. The lack of information has led to external consultation, for example: tequila workers "are the most active in the search for information in the COECyT $^{1}$ index" (Interview 2). Despite this, the environment about the information is negative: it is scarce... expensive and owned by both large companies and the figure of master tequilier. "The information is owned by large companies ... There is no mastery of technology, process... and manufacturing... because it is given orally. It depends on each master the texture and aroma of tequila" (Interview 4).

\section{Internalization:-}

The findings showed that agreements for the transfer of knowledge are being promoted. "There is a transfer of technology and knowledge in the diploma in tequila technician" (Interview 3). In the absence of information, such certified was created by the $\mathrm{CRT}^{2}$ and $\mathrm{UAG}^{3}$ with the aim of promoting mutual learning; however, not all tequila companies participate. Within the courses (certified) there is transfer of knowledge, which does not happen between companies, because the dynamics of a diploma facilitates it (Interview 4). There is a change of vision around the use of knowledge; therefore, it is feasible "that empirical knowledge be transmitted to the new generations. These people of handmade methods of all their life are willing to transmit their knowledge" (Interview 6).

CRT has worked to promote integration through training programs such as the diploma in tequila technician, where tequila industry members can share their knowledge. An example of this is the fact that companies use "sophisticated packaging. They sell tequila, but also sell a very sophisticated bottle" (Interview 9). The process of knowledge transfer is taking place because the companies are concentrated, allowing the development of certain forms of training (Interview 9).

Together with innovation and the use of technology, they are putting the traditional tequila process as a value-added generation. "Ancestral technique is to maintain the original techniques for the tequila. I hold some artisan elements and that gives me prestige... I produce less, but the flavor is better" (Interview 8). Also, another important element is the designation of origin, which "has been the key point in the evolution of the tequila industry. Why is this

\footnotetext{
${ }^{1}$ COECyT: State Council of Science and Technology of the State of Jalisco. It is also known as COECyTJal

2 Tequila Regulatory Council.

${ }^{3}$ Autonomous University of Guadalajara
} 
important? Because, to get the appellation of origin, the CRT has done its part in science and technology, certifications, and standards" (Interview 2).

Table 1:- Quantitative results $(N=39)$

\begin{tabular}{|c|c|c|}
\hline Items & $\boldsymbol{M}$ & SD \\
\hline 1. New things are being done & 3.94 & .867 \\
\hline 2. We try to understand the other's way of thinking & 3.80 & .670 \\
\hline 3. We seek to understand the viewpoint of all the people. & 3.88 & .824 \\
\hline Socialization & $\mathbf{3 . 8 7}$ & $\mathbf{. 7 8 7}$ \\
\hline 4. Development Reports & 3.54 & 1.092 \\
\hline 5. The dissemination of knowledge is encouraged & 3.14 & 1.107 \\
\hline 6. Progress reports are distributed & 3.16 & 1.201 \\
\hline Externalization & $\mathbf{3 . 2 8}$ & $\mathbf{1 . 1 3 3}$ \\
\hline 7. Files contain information to improve tasks & 3.56 & 1.091 \\
\hline 8. Company provides information & 3.42 & 1.090 \\
\hline 9. Information available in files and databases & 3.52 & 1.035 \\
\hline Combination & $\mathbf{3 . 5 0}$ & $\mathbf{1 . 0 7 3}$ \\
\hline 10. Partnerships to promote learning & 3.42 & 0.88 \\
\hline 11. Suggestions are taken into account & 3.74 & .96 \\
\hline Internalization & $\mathbf{3 . 5 3}$ & $\mathbf{0 . 9 2}$ \\
\hline
\end{tabular}

Source. Own elaboration based on Mihi et al (2011).

$\mathrm{M}=$ Mean

$\mathrm{SD}=$ Standard Deviation

Currently there are optimistic visions. "You go with them (micro-enterprises) and have sanitary equipment, there are those who use the oven, the autoclave, and some use the distillation tower or the process of extracting cold. They use the most recent system" (Interview 4). On the other hand, about infrastructure, tequila companies in the region are in the vanguard, they are pointers. They have the best because it is their way of growing, they are upgrading in equipment infrastructure (Interview 5).

There is a "technological development in terms of processes and machines" (Interview 1), because it is a sector that has been opened drastically to the use of technology and information (Interview 2), where changes have been made in the implementation of technology within processes. "The industry has tried to adapt... Leading companies have had an innovation boom... There have been some changes without losing the essence of the product" (Interview 4). However, there is still a lot to do. In this industry, an exception of the leading companies, investment in research is low, there is a lack of personnel with research training and there is a disconnection between industry, research centers and universities. "Patents is a pending issue" (Interview 2), because "innovation is little" (Interview 4).

The quantitative findings of the interviews are shown in Figures 1-4, which aim to outline the KM process in the tequila industry. 
Figure 1:- Socialization $(N=9)$.

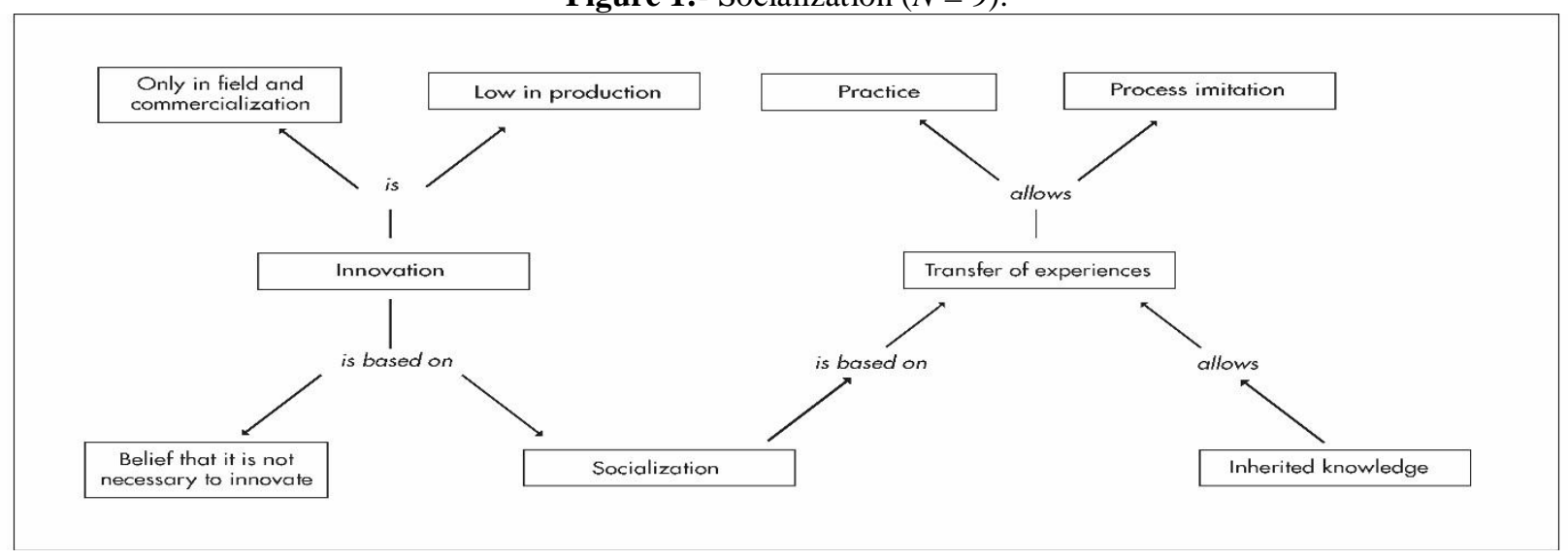

Figure 2:- Externalization $(N=9)$.

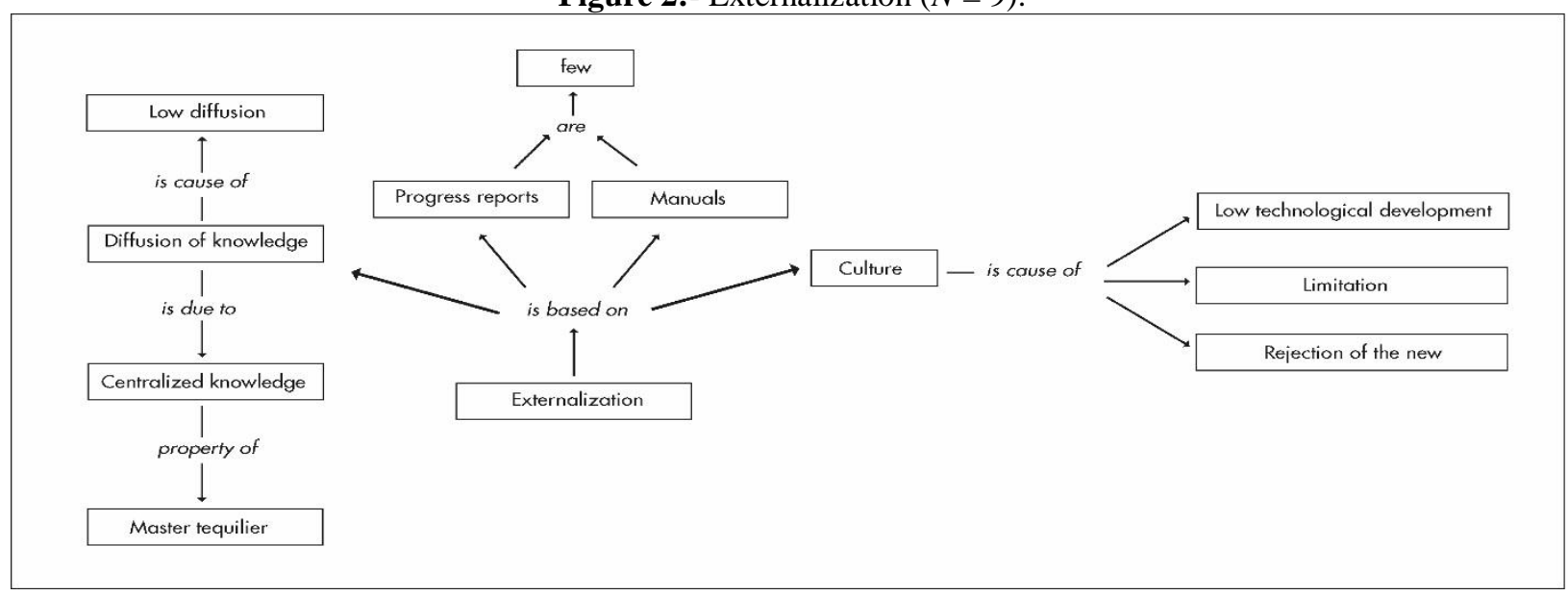

Figure 3:- Combination $(N=9)$.

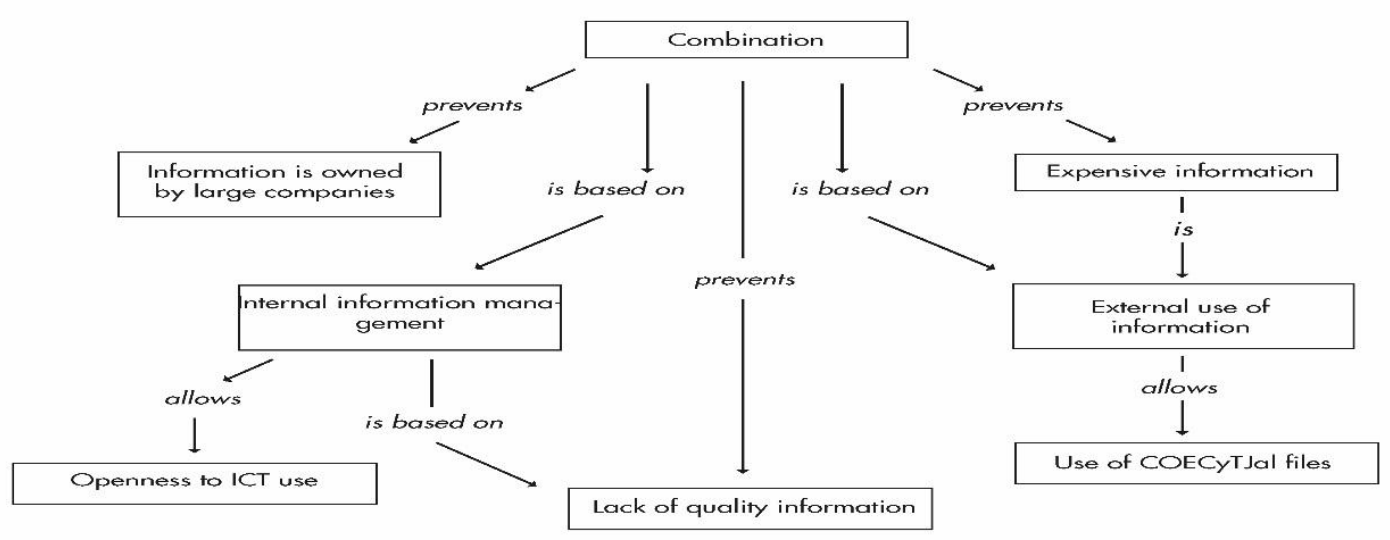


Figure 4:- Internalization $(N=9)$

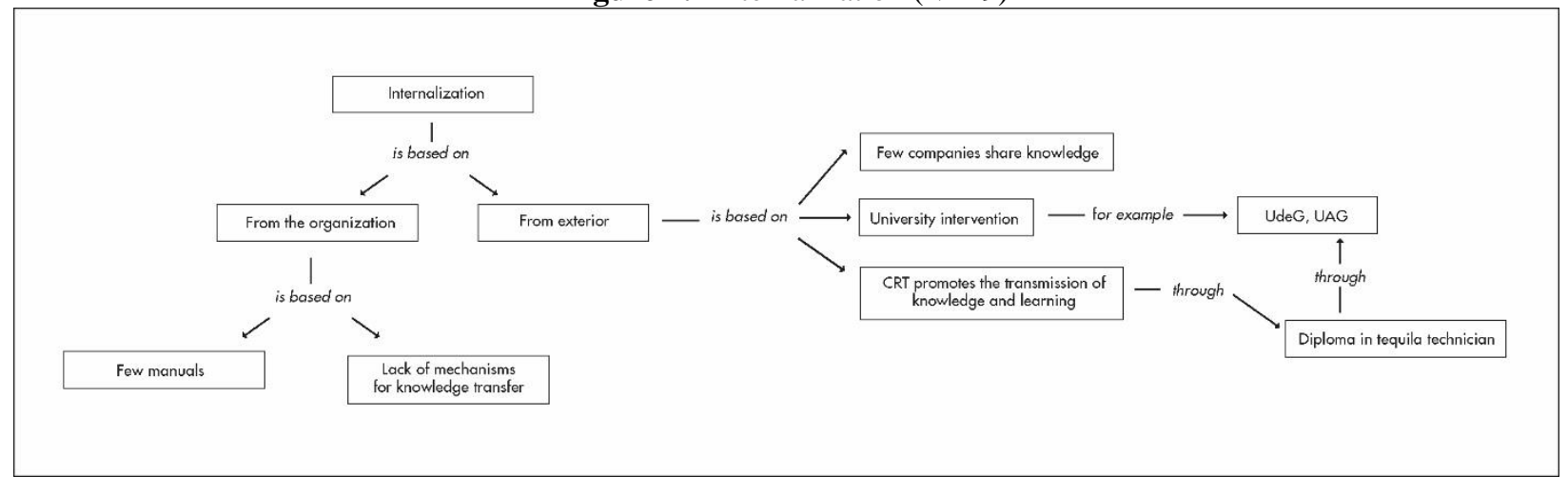

Source: Own elaboration.

$\mathrm{UdeG}=$ University of Guadalajara.

The emergence and development of systems for the creation and management of knowledge are due to the change in the socioeconomic system. Now, knowledge has been considered as one of the main resources to compete (Brooking, 1997), which is a source of competitive advantages (Grant, 1996; Steward, 1998). The three leading companies in the tequila industry have been aware of the importance of managing knowledge (Casas, 2006); however, not all its members of this industry use it. It has even been observed that KM has not been considered as a strategic resource for these enterprises (Boonman, 2009; Bowen, 2012).

Through the present mixed study it was possible to explore, and at the same time, contrasting the visions of two elementary participants for the development of tequila: companies and academics. It was found that many companies are opening to a new knowledge economy; however, the process is unfinished within the stages of the SECI model. "It is evident that within the tequila industry, there are two worlds" (Interview 8). On one side are the three oligopolistic companies (Martínez, 2008), which have been seen in the KM as a resource to ensure leadership (Casas, 2006). On the other side are the MSMEs, which are deficient in applying the SECI model, where the process is the fragment. It is partially fulfilled in certain stages, what does not allow tacit knowledge to become explicit.

Within the socialization, it is possible to affirm the existence of the conversion of tacit to explicit knowledge. There is transference in employment of experience through practice and imitation of processes. The negative part in the stage is the innovation, which is only done in some parts of the value chain (e.g. agronomy and commercialization). This assertion coincides with Massieu (2000), who found deficiencies in terms of innovation and the use of technology. In addition, dominant companies are unique using innovation and technology (Martínez, 2008).

Externalization was the stage of the process that presented the most deficiencies. On one hand, problems were encountered in the preparation of manuals that allow the standardization of processes; while on the other, the master tequilier was found, who monopolizes knowledge and uses it as a way of exercising control over the organization. It was observed the need to elaborate Strategies to transfer the knowledge that is property of the master tequilier and so store it in the manuals.

Regarding the combination, the need to facilitate information was found, which is small, external and expensive. Also, technology transfer is required (COFPRO, 2003). In spite of this, companies are opening up to the use of ICT, and this change is due to the participation of COECyTJal. Internalization showed a favorable advance from the external participation of institutions such as the CRT, COECyTJal and universities. An example of it, is the training offered within the diploma in tequila technician, where there is a greater promotion of KM. In order to develop the combination of knowledge within the SECI, it is required that the fruits of this certified are reflected in products such as manuals and databases.

\section{Conclusion:-}

The progress of the industry in terms of KM can be an example of triple-helix work: government, companies and universities. Despite this, the implementation of certain changes to use knowledge as a strategic resource is still lacking which allow for tequila industry be in front of other drinks like vodka. Through the findings of the present 
investigation, In a conclusive way, four basic strategies are proposed to improve knowledge management process within tequila industry: 1) Dissemination of a new business culture within the members of the industry, aimed at the development of intangible assets such as knowledge; 2) elaboration of manuals inside and outside of companies, with easy access both physical and digital; 3) Reduce the power and protagonism of the figure of the master tequilier, creating mechanisms to compare his knowledge; y 4) Promote the participation of all companies, especially MSMEs in the diploma in tequila technician and other training activities.

The present investigation has some limitations. First, the size of the quantitative sample $(N=39)$, which was very small and not representative of the population; As well as the lack of probabilistic sampling. Regarding the number of interviews $(N=9)$, it was not possible to interview several relevant researchers on the subject. For future research is sought to solve limitations with the aim of achieving a greater approach to the phenomenon of study and being able to make bigger inferences. In addition, it is advisable to carry out the research again for a longitudinal study.

\section{Acknowledgement:-}

This work was supported in part by Instituto Tecnológico de Sonora through the "Program for the Support and Development of Research Projects" (PROFAPI, by its Spanish acronym).

\section{References:-}

1. Barney, J. (1991). Firm Resources and sustained competitive advantage. Journal of Management. 1(17): 99120.

2. Boonman, T. (2009). Efecto tamaño en las estrategias de las empresas tequileras ante el ciclo del agave: un estudio exploratorio. [The size effect in strategies of tequila producers to manage the agave cycle: An exploratory study]. Carta Económica Regional. 21(102): 111-132.

3. Bowen, S. (2012). Las indicaciones geográficas, la globalización y el desarrollo territorial: El caso del tequila. [Geographical indications, globalization and territorial development: The case of tequila]. Agroalimentaria. 18(34): 91-103.

4. Brooking, A. (1997). El capital intelectual, el principal activo de las empresas del tercer milenio. [The intellectual capital, core for the third millennium]. Paidós. Barcelona, Spain.

5. Bueno, E. (1999). La gestión del conocimiento: Nuevos perfiles profesionales. [Knowledge management: New professional profiles]. Boletín de Estudios Económicos. 3(164): 207-229.

6. Casalet, M. (2010). El tránsito de México hacia la economía basada en el Conocimiento. [Mexico's Transition to the Knowledge-Based Economy]. Ideas CONCYTEG. 5(6): 109-116.

7. Casas, R. (2006). Between traditions and modernity technological strategies in three tequila firms. Technology in Society. 28(3): 407-419.

8. Coelho, A. (2007). Eficiencia colectiva y upgranding en el clúster del tequila. [Collective efficiency and upgranding in the tequila cluster]. Análisis Económico. 22(49):169-194.

9. COFUPRO. (2003). Caracterización de la cadena agroalimentaria/agroindustrial nacional e identificación de sus demandas tecnológicas. [Characterization of the agro-food chain / national agro-industry and identification of their technological demands]. Programa Nacional Estratégico de Necedades de Investigación y de Transferencia de Tecnología. Mexico.

10. Díaz, O. H (2007). La productividad de las empresas fabricantes de tequila en Jalisco. [The productivity of tequila manufacturers in Jalisco]. Carta Económica Regional. 19(99): 40-45.

11. Drucker, P. (1969). The age of discontinuity: Guidelines to our changing society. Harper \& Row. New York. York. U.S.

12. Edwards, J., Collier P., and Shaw D. (2005). Knowledge Management and its impact on the management accountant. Aston Business School, Aston University. London. U.K.

13. Ferrater, J (1964). Diccionario de filosofía. [Dictionary of Philosophy]. 5th. Ed. Editorial Sudamericana. Buenos Aires. Argentina.

14. Grant, R. (1996). Toward a knowledge-based theory of the firm. Strategic Management Journal. 17: 109-122.

15. Interview 1 (2013). Entrevista sobre gestión del conocimiento en la industria tequilera [Interview on knowledge management in the tequila industry] (12-2-13). Entrevistador Marco Núñez. Jalisco. México.

16. Interview 2 (2013). Entrevista sobre gestión del conocimiento en la industria tequilera [Interview on knowledge management in the tequila industry] (5-3-13). Interviewer: Marco Núñez. Jalisco. México.

17. Interview 3 (2013). Entrevista sobre gestión del conocimiento en la industria tequilera [Interview on knowledge management in the tequila industry] (13-3-13). Interviewer: Marco Núñez. Jalisco. México. 
18. Interview 4 (2013). Entrevista sobre gestión del conocimiento en la industria tequilera [Interview on knowledge management in the tequila industry] (19-4-13). Interviewer: Marco Núñez. Jalisco. México.

19. Interview 5 (2013). Entrevista sobre gestión del conocimiento en la industria tequilera [Interview on knowledge management in the tequila industry] (7-5-13). Interviewer: Marco Núñez. Jalisco. México.

20. Interview 6 (2013). Entrevista sobre gestión del conocimiento en la industria tequilera [Interview on knowledge management in the tequila industry] (13-5-13). Interviewer: Marco Núñez. Jalisco. México.

21. Interview 7 (2013). Entrevista sobre gestión del conocimiento en la industria tequilera [Interview on knowledge management in the tequila industry] (14-5-13). Interviewer: Marco Núñez. Jalisco. México.

22. Interview 8 (2013). Entrevista sobre gestión del conocimiento en la industria tequilera [Interview on knowledge management in the tequila industry] (19-5-13). Interviewer: Marco Núñez. Jalisco. México.

23. Interview 9 (2013). Entrevista sobre gestión del conocimiento en la industria tequilera [Interview on knowledge management in the tequila industry] (27-5-13). Interviewer: Marco Núñez. Jalisco. México.

24. Luna, R. (2009). Análisis del mercado nacional y norteamericano del tequila. Continuidades y tendencias recientes. [Analysis of the national and North American tequila market. Continuities and trends]. Carta Económica Regional. 23/24(108/110):37-58.

25. Machlup, F. (1962). The production and distribution of knowledge in the United States. Princeton University Press. New Jersey. U.S.

26. Macías, A. (1997). Organización de la Industria del Tequila. [Organization of the Tequila Industry]. Carta Económica Regional. 9(54):3-10.

27. Macías, A. (2001). El clúster en la Industria del Tequila en Jalisco, México. [The Cluster in the Tequila Industry in Jalisco, Mexico]. Agroalimentaria. 13(13): 57-72.

28. Macías, A., and Valenzuela A.G. (2009). El tequila en tiempos de la mundialización. [Tequila in times of globalization]. Comercio. 50(6): 459-471.

29. Massieu, Y. (2000). Estrategias Empresariales Globales y Agroexportaciones Mexicanas: Ahora el Tequila. [Global Business Strategies and Mexican Agroexports: Now the Tequila]. El Cotidiano. 16(99):103-112.

30. Madrigal, B.E. and Núñez M.N (2013). Discusión teórica gestión del conocimiento, paradigmas, modelos e indicadores. Caballero F. and Ramírez J.A (Coordinadores). La gestión y transferencia del conocimiento en México: casos de estudio. [The management and transfer of knowledge in Mexico: case studies]. (pp. 9-33). MAPorrúa. Mexico.

31. Mihi, A., García, V.J., and Rojas, R.M. (2011). Knowledge creation, organization learning and their effects on organizational performance. Inzinerine Ekonomika-Engineering Economics. 3(22): 309-318.

32. Nataliya, A. I., and Inciarte, A. (2012). Fenomenología y hermenéutica: dos perspectivas para estudiar las ciencias sociales y humanas. [Phenomenology and hermeneutics: two perspectives for studying social sciences and the humanities]. Multiciencias. 12(2):199-205.

33. Nonaka, I. (1991). The knowledge-creating company. Harvard Business Review. 96-104.

34. Nonaka, I. (1994). A dynamic theory of knowledge creation. Organizational Science. 5(1): 14-37.

35. Nonaka, I. and Takeuchi H.(1995). The Knowledge-Creating Company. How Japanese companies create the dynamics of innovation. Oxford University Press. New York. U.S.

36. Obeso, C. (2003). Capital intelectual. [Intellectual capital]. Ediciones Gestión 2000. Barcelona, Spain.

37. Roos, J., Roos, G., Dragonetti, N., and Edvinsson, L. (2001). Capital Intelectual. El intangible de la empresa. [Intellectual capital. The intangible of the company]. Paidós. Barcelona. Spain.

38. Rulfo, F., Pérez, J.F., Del Real J., and Keir, F.B. (2007). Conocimiento y prácticas agronómicas para la producción de Agave tequilana Weber en la zona de denominación de Origen del tequila. [Knowledge and agronomic practices for the production of Agave tequilana Weber in the area of denomination of Origin of tequila]. Instituto Nacional de Investigaciones Forestales, Agrícolas y Pecuarias. Centro de Investigación Regional del Pacífico Centro. Jalisco. Mexico.

39. Stewart, T. (1998). La nueva riqueza de las organizaciones: el capital intelectual. [Intellectual capital: The new wealth of organizations]. Ediciones Granica. Barcelona, Spain.

40. Walton, M. (1977). The evolution and localization of mezcal and tequila in Mexico. [The evolution and location of mezcal and tequila in Mexico]. Revista Geográfica. (85): 113-132.

41. Wiig, K. (1997). Integrating intellectual capital and knowledge management. Long Range Planning. 30(3): 399405 . 